\section{Americanismo e fordismo. Antonio Gramsci. São Paulo: Hedra, 2008, 96 p.}

\section{Lúcia Maria Wanderley Neves}

Escola Politécnica de Saúde Joaquim Venâncio, Fiocruz, Rio de Janeiro, Brasil

$<$ lucianeves@fiocruz.br >

É sempre bem-vinda uma iniciativa editorial que traga às novas gerações obras marxistas em tempos de um antimarxismo explícito ou subliminar, presente na literatura, que tenta dar conta das mudanças que se processam na atualidade mundial e brasileira e que fundamenta a formação dos cientistas sociais nos anos iniciais do século XXI. Antimarxismo que vem atingindo até mesmo Antonio Gramsci, autor que, até pouco tempo, pelo menos no Brasil, era citado por um largo espectro das forças políticas nacionias.

O "Americanismo e fordismo", título dado pelo próprio Gramsci ao Caderno 22 dos Cadernos do cárcere, em 1934, composto de 16 notas, é conhecido dos brasileiros de longa data. Ele foi editado no Brasil em 1968, pela Civilização Brasileira, na chamada edição temática, como parte do livro Maquiavel, a política e o Estado moderno, com tradução de Luiz Mário Gazzaneo. Mais recentemente, em 2001, novamente pela Civilização Brasileira, ele se inclui no volume 4, Temas de cultura, ação católica. Americanismo e fordismo, da edição brasileira da íntegra dos Cadernos do cárcere, editada por Carlos Nelson Coutinho e Luiz Sérgio Henriques.

Agora, a editora Hedra nos brinda com este trecho específico da complexa e abrangente reflexão de Antonio Gramsci, traduzido por Gabriel Bogossian, com introdução e notas técnicas dos professores Ruy Braga e Álvaro Bianchi, das universidades de São Paulo e de Campinas, respectivamente.

Este recorte feito pela editora Hedra no conjunto do universo gramsciano tem como objetivo, segundo o professor Ruy Braga, no final da introdução às notas do Caderno 22, contribuir para a reflexão sobre a atual conjuntura internacional, "no instante em que a crise econômica estadunidense catalisada pelo colapso do financiamento imobiliário subprime nos rememora aquela outra de 1929" (p. 25).
A introdução ao texto foi dividida em duas partes, precedida de um rápido preâmbulo no qual situa a relevância atribuída por Gramsci a esse bloco histórico, denominado de americanismo e fordismo, no conjunto dos seus escritos do cárcere. Na primeira parte, intitulada "Hegemonia estadunidense", o autor ressalta primeiramente a abrangência atribuída por Gramsci ao fenômeno do americanismo. Observa também que, por envolver as dimensões econômica, política e ideológica, este fenômeno passa a constituir-se em um novo modo de vida, profundamente imbricado na esfera produtiva com o taylorismo e o fordismo. Chama a atenção ainda para o deslocamento do eixo dinâmico da economia mundial da Europa para os Estados Unidos, provocado por este fenômeno. Salienta ainda que o marxista italiano privilegia nessas notas "a organização do trabalho e da produção social do consentimento na indústria moderna", realçando que o fordismo, ao se expandir da fábrica para o conjunto das relações sociais de produção, propicia a criação de um novo tipo de trabalhador, conformado a partir da conjugação dos elementos da força e do consentimento. Por fim, o autor destaca ainda a percepção gramsciana de que o 'fenômeno americano', aparecendo como uma resposta à queda tendencial da taxa de lucro, se constitui em estratégia burguesa de superação da crise de hegemonia em processo à época.

Na segunda parte da introdução, denominada "A dialética da pacificação", o professor Ruy Braga salienta que, no americanismo e fordismo, a burguesia estadunidense alcança sua elaboração 'superior', distinguindose das classes dominantes tradicionais. Essas novas frações hegemônicas fundam um novo Estado que amplia suas esferas estruturais, para além da aparelhagem estatal, com a expansão de aparelhos privados de hegemonia na sociedade civil. Esse Estado ampliado efetiva a passagem de um individualismo econômico característico das fases anteriores do capitalismo para uma economia programática, viabilizadora de novas relações sociais, baseadas no consumo de massas; aumenta a produtividade capitalista; efetiva a pacificação das classes trabalhadoras e, ao mesmo tempo, restaura a hegemonia burguesa abalada por um período significativo de crise orgânica. 
Salienta, por fim, na análise do americanismo e fordismo, o seu caráter de revolução passiva.

Tais observações introdutórias ao texto gramsciano levam o professor Ruy Braga a concluir que "americanismo e fordismo representam as duas faces de uma mesma moeda": um processo de racionalização do trabalho e da produção e, ao mesmo tempo, um novo ajuste entre estrutura e superestrutura, “(...) no sentido de recompor a unidade entre as relações sociais de produção e os aparelhos de hegemonia" (p. 25).

Comparando a edição da Civilização Brasileira de Americanismo e fordismo, de 2001, com esta nova edição da editora Hedra, de 2008, podemos observar que esta última tenta atribuir maior leveza ao texto, dando às notas uma aparência de ensaio, especialmente quando traz para notas de rodapé trechos em que Gramsci intercala observações paralelas. Percebe-se, ainda, nessa perspectiva, uma tentativa de dar maior clareza aos parágrafos, subdividindo-os em frases mais curtas.

Não obstante esses recursos tornem, de fato, a leitura mais fácil e estimulante ao leitor iniciante, retiram, em parte, o caráter fragmentário da escrita das notas, característica fundamental dos Cadernos do cárcere, em que pese a robustez e a organicidade do seu pensamento.

Merecem destaque ainda, no tocante à tradução, certas discrepâncias significativas entre a edição de 2001 e a de 2008 , algumas quanto à imprecisão no uso da língua portuguesa, outras no que se refere a divergências no próprio conteúdo. Essas imprecisões de conteúdo e forma podem ser verificadas, por exemplo, na nota 11, na página 71. Enquanto a editora Hedra traduziu: "O industrial americano se preocupa em manter a continuidade da eficiência física do trabalhador, da sua eficiência muscular e nervosa. É seu interesse ter uma competência estável, um complexo harmonizado permanentemente, porque até o complexo humano - o coletivo trabalhador - de uma grande empresa é uma máquina que não deve ser desmontada com grande freqüência, nem ver renovados os seus pedaços individuais sem grandes perdas", a edição de 2001, na página 267, traduz esse mesmo trecho de maneira diversa, certamente mais adequada em termos conceituais: "O industrial americano se preocupa em manter a continuidade da eficiência física do trabalhador, de sua eficiência muscular-nervosa: é de seu interesse ter um quadro estável de trabalhadores qualificados, um conjunto permanente harmonizado, já que também o complexo humano (o trabalhador coletivo) de uma empresa é uma máquina que não deve ser excessivamente desmontada com freqüência ou ter suas peças individuais renovadas constantemente sem que isso provoque grandes perdas."

Em que pese estas e outras imprecisões verificadas, esta nova tradução tem o mérito de trazer mais uma vez à tona a atualidade impressionante do pensamento gramsciano, por apontar e discutir, neste trecho e no conjunto de sua obra, temas pertinentes à pauta da agenda política mundial e nacional desses anos iniciais do século XXI, tão bem destacados pelo professor Ruy Braga na introdução.

A leitura desta nova edição deve se traduzir em um convite para um aprofundamento do estudo das idéias gramscianas, cuja obra completa está à disposição do leitor brasileiro nos dois volumes das Cartas do cárcere, nos dois volumes dos Escritos politicos e nos seis volumes dos Cadernos do cárcere, todos publicados pela editora Civilização Brasileira. 